Association, the Paint Research Association and the Rubber Research Association will also be represented. Lectures have also been arranged to take place at 8 p.m. on March 3, 10, 17 and 24.

\section{Palæobiology and Biostratigraphy}

DR. H. G. Schenck has published an exhaustive monograph of "Nuculid Bivalves of the genus Acila" (Geological Society of America, Special Papers No. 4 ; 1936). A critical descriptive catalogue of the twentyfive known species and varieties is arranged in the order of their age, from Cretaceous to Recent, and is illustrated by eighteen admirable plates which give a complete iconography of the genus. The systematic part of the work is preceded by the morphology of the shell and by an account of the anatomy, habits and habitats of the living animal. The terms 'paleobiology' and 'biostratigraphy' are used hopefully, but no radically new methods are apparent to correspond with them. Ever since palæontology has been rationally studied, its best workers have used the anatomy, the habits and habitats of living creatures to explain the debris of their precursors. The method requires caution, for some animal genera have changed their mode of life. The marine mollusc Pholadomya, for example, is now abyssal ; in Jurassic times it lived in shallow water and, so late as the Eocene, it is found in sediments which give no indication of very deep seas. Dr. Schenck was led to this study by the problems of the Oligocene in the United States Pacific coastal areas. His results help to solve these problems, not by any a priori palæobiology, but by the accurate delimitation of fossil species and by showing that they are associated with distinct faunas in a sequence of strata. This is not a new method, but it is the only sound one, for all our knowledge of the succession of forms of life is from stratigraphy, which, somewhere or other, must be based upon visible superposition. Terms like 'zone', 'age', 'epoch' are discussed. Palæontologists did not invent these words, which are still current in ordinary speech, so that we can doubt the wisdom of restricting their meaning, for their common, vague sense is sure to lodge in runaway minds and cause confusion.

\section{Investigation into Brood Diseases of Bees}

IN May 1934, an investigation into the brood diseases of bees was commenced at Rothamsted Experimental Station, the British Bee-Keepers' Association undertaking to supply half the annual cost of the work ( $£ 250$ per annum) and the Agricultural Research Council the remainder. As a result, Dr. H. L. A. Tarr was appointed, and has worked continuously on the problem since that time. $\mathrm{He}$ has confirmed the fact that American foul brood is caused by a spore-forming organism, Bacillus larvae, and that its incidence is independent of the strength of the bee colony. European foul brood, on the other hand, is a disease which usually affects weak colonies of bees early in the brood-rearing season, and is probably caused by Bacillus pluton, a curious organism which has so far resisted all attempts made to cultivate it, in association with other organisms. He has also shown that a third condition known as addled brood is very, prevalent in Great. Britain, and has constituted almost one third of the cases of brood disease sent in for examination. The Bee Research. Committee at Rothamsted and the British Bee-Keepers' Association are unanimously of the opinion that the investigation should be continued, particularly in connexion with methods of treatment, but the latter have asked that Rothamsted should collect the contributions directly. The Agricultural Research Council has sanctioned an increased grant of $£ 300$ for the current year on condition that a sum of not less than $£ 250$ is collected from other sources. In the circumstances, Rothamsted Experimental Station is making an appeal for contributions from interested individuals in order that this important investigation may be continued.

\section{Sperm Whale at the Natural History Museum}

The skeleton of the sperm whale stranded at Bridlington on January 25 has now reached the British Museum (Natural History). The animal from which the skeleton was taken was a male 59 feet in length. In the sperm whale, the male is fully grown at about 65 feet, whereas females have not been recorded exceeding 40 feet in length. The sperm whale or cachalot belongs to the division of the Cetacea known as toothed whales or Odontoceti. The Bridlington animal had thirty pairs of teeth in the lower jaw (all unfortunately removed by souvenir hunters) and three small tooth vestiges on one side of the upper jaw. The whole skeleton weighed between four and five tons, of which weight the skull accounted for more than three tons. The sperm whale is not a common animal in British waters, only about six strandings having occurred in the last twenty-five years. It prefers the warmer tropical and sub. tropical seas. Sperm whales stranded on British shores are almost invariably large old males, and it has been suggested that they are animals which havo been driven out from the main herd by younger and more vigorous bulls. The present stranding is there. fore rather remarkable. The Museum is informed by coastguards of all Cetacea stranded on the British coasts, and specimens are obtained whenever desirable and practicable. On an average, there are about sixty such strandings in the year. Stranded whales, being "Fishes Royal," are the property of the Crown, and are handed over to the Museum by the authorities concerned.

\section{Botany in China}

IN a paper presented at the annual conference of the International Faculty of Sciences, held in London on January 29-30, Prof. H. H. Hu described the progress of botanical sciences in China. Botany in China is a very modern study, having a history of only a quarter of a century, though, of course, the medicinal study of herbs in ancient China is well known. At present, taxonomy takes pride of place, which is natural in a country so rich in botanical 